\title{
PROFILE OF PRACTITIONERS OF SUPERVISED PHYSICAL EXERCISE IN THE SOUTHERN REGION OF BRAZIL
}

\author{
PERFIL DOS PRATICANTES DE EXERCÍCIO FÍSICO SUPERVISIONADO DA \\ REGIÃO SUL DO BRASIL
}

\section{Diego Limberger WELTER'; Eduardo Borba NEVES²; Francisco José Félix SAAVEDRA ${ }^{3}$}

1. Mestre em Ciência do Desporto, Universidade de Trás-os-Montes e Alto Douro, UTAD, Portugal. diegolwelter@gmail.com; 2. Instituto de Pesquisa da Capacitação Física do Exército - IPCFEX, Portugal; 3. Universidade de Trás-os-Montes e Alto Douro; Centro de Investigação em Desporto Saúde e Desenvolvimento Humano, Portugal.

\begin{abstract}
With 23,398 fitness academies, catering for around seven million users, Brazil ranks second behind the United States in the number of units. The objective of this study is to delineate the profile of supervised physical activity practitioners in the three most southern states of Brazil (Paraná, Santa Catarina, and Rio Grande do Sul), analyzing the reasons which lead them to choose a fitness service. Fitness academy clients were also surveyed in relation to their alcohol, tobacco and food supplement usage. Seven hundred and ninety-seven (797) people were evaluated by means of a questionnaire. Data was collected in 24 fitness academies (eight in each state) in the three most southern states of Brazil. It was observed that those who practiced exercise regularly at fitness academies smoked little, consumed few food supplements, and with $(50.44 \%)$ of those surveyed stating that they consumed only moderate amounts of alcohol. The majority, (34.13\%) of exercise practitioners in southern Brazil chose to go to the gym five times a week, (40.99\%) went at night, with (40.56\%) giving as their reason for practicing exercise as being a way to improve their health. The distance between their home and the gym was the most important reason in choosing a place to conduct training. Intense individual activities were the most practiced type of exercise, there being no statistical difference between the percentages in the three states.
\end{abstract}

KEYWORDS: Profile of sports. Fitness Academies in Southern Brazil. Consumer profile.

\section{INTRODUCTION}

With 23,398 fitness academies, catering for around seven million users, Brazil ranks second behind the United States in the number of units. According to the International Health \& Racquet Sports Club Association (IHRSA, 2014), in the United States had 30,500 units. Market data shows that Brazilians have a great willingness to participate in physical activities during their leisure time (SEBRAE, 2015) partly due to public awareness of the beneficial effects of exercise, as opposed to the downside of being sedentary and overweight resulting in the shortening of life expectancy and negative impacts on the quality of life (WHO, 2014). The relentless pursuit of an aesthetic model idealized by the media may also be a factor in determining the reason why people practice supervised physical activities.

Even with increasing numbers practicing physical exercise, only a small part of the national population exercise satisfactorily, as shown by statistics from the Ministério da Saúde do Brasil (MSB, 2013), which states that only $15.2 \%$ of the population practice physical activity in the way recommended. Moura et al (2008) reported that $14.9 \%$ of adults practiced 30 minutes of light or moderate physical activity on five or more days in the week or 20 minutes of vigorous activity three or more days in the week.

It is evident therefore that there is a lot of room for growth in the regular physical exercise market in Brazil especially considering that obesity has become a major worldwide epidemic (WHO, 2014), with $43.0 \%$ of Brazils population being considered overweight (MOURA, 2008). Malta, Andrade, Claro, Berna, \& Monteiro (2014), states that the number of Brazilians overweight had increased by more than one percentage point. Estimating the Body Mass Index (BMI) of the population attending fitness academies is important in order to verify how physically active clients are in relation to weight ratios and the activities they should practice.

It is important to study Brazilian habits that may contribute to the development of metabolic syndromes relating to regular consumption of tobacco and alcohol. WHO (2008) states that smoking is the leading cause of premature death from such things as preventable diseases and disabilities in developed countries. The Diretoria de Saúde de Portugal (DGS, 2013) states that the main causes of smoking-related deaths are respiratory diseases, cardiovascular diseases and 
cancer. Obesity is also a risk factor for coronary heart disease (ACSM, 2007).

Given the benefit of exercise in changing body composition (ACSM, 2006) and metabolic, physiological and psychological parameters (ACSM, 2007) it is relevant to evaluate; what type of exercise that is practiced in southern Brazil, the objectives of academy clients, the correlation of results according to weekly frequency, activity mode chosen, the type and consumption of food supplements which help in the process.

Soler,et al (2013) argues that an increase in tolerance intensity, or the exercise session time is related to training frequently. Carvalho (2011) stated in their research that practitioners who attend the gym more than three times a week were happier people.

IHRSA (2014) found that in the US the main reason given by clients for practicing exercise in a fitness academy was to; stay healthy, followed by a desire to feel better about one self. Ascensão (2012) found that the reasons that prompt people to adherence to physical exercise at gyms were: well being, health, stress reduction and physical fitness conditioning. Fermino, Pezzini, \& Reis (2010) concluded that health, fitness; desire to do things, attractiveness and harmony was the main motivators for regular exercise, regardless of sex, body fat percentage and BMI.

Considering the above, the objective of this study was to delineate the profile of supervised physical activity practitioners in the southern region of Brazil, analyzing the reasons that led them to choose a fitness service as well as their profiles in relation to alcohol, tobacco and food supplements.

\section{MATERIAL AND METHODS}

Seven hundred and ninety-seven (797) volunteers were evaluated, three hundred and twenty six (SOLER, 2013) males and four hundred and sixty two (462) females, resident in the two most populous cities in each state in southern Brazil (IBGE, 2010). The municipalities used as a reference in the state of Parana (PR) were Curitiba and Londrina, (where 312 people were surveyed), in the state of Santa Catarina (SC), Joinville and Florianópolis, (where 272 people were surveyed), in Rio Grande do Sul (RS), Porto Alegre and Caxias do Sul, (where 213 people were surveyed). Twenty four fitness academies were randomly selected, four in each city in which the research was conducted, totaling eight academies in each state. All the academies selected agreed to participate in the research project.
The samples were obtained in the period from May to September 2015. The participants who agreed to participate in the survey were entering or leaving in the fitness academy at the time of the data collection, and were aged between 12 and 80 years old. All participants signed an informed consent term, (minors having their terms signed by their legal guardians), and the collection of data was conducted in accordance with the principles proposed by Resolution 466/2012 of the Conselho Nacional de Saúde (National Health Council). The study was approved by the Comitê de Ética em Pesquisa (Committee for Ethics in Research) under the CAAE number: 39816114.0.0000.5365 of Instituto de Ensino Superior e Centro Educacional Luterano Bom Jesus, with the opinion number 1.044.918/2015.

The volunteers were instructed to answer a closed questionnaire with twelve objective questions directed towards: physical profile in order to establish BMI; Cigarette consumption profile, alcohol and food supplements used; profile of sports practiced, in order to verify what led the interviewee to choose a particular academy, how they exercised and for what purpose and what was the monetary amount they were investing monthly in their training.

After the questionnaires were tabulated using Microsoft Office Excel 2010, data analysis was undertaken using Statistical Package for Social Sciences software (version 20.0, SPSS Inc, Chicago). Frequency tables, to characterize the sample were used, as well as measures of central tendency (mean) and dispersion (standard deviation). The analysis of adherence to normality was verified by the Kolmogorov-Smirnov test with the Lilliefors correction. Inferential analysis and comparison between groups we used analysis of variance of a path (one-way ANOVA) with post hoc Bonferroni. The chi-square test $(\chi 2)$ was used to compare the profile of physical activity between regions. All statistics were analyzed considering a significance level of $95 \%(\mathrm{p}=0.05)$.

\section{RESULTS}

The mean BMI of the questioned population was $24.77( \pm 3.54) \mathrm{kg} / \mathrm{m}^{2}$, which is considered a healthy standard. The state with the highest BMI was the Rio Grande do Sul, with a score of 24.85 ( \pm $3.67) \mathrm{kg} / \mathrm{m}^{2}$, followed by Paraná with $24.80( \pm$ $3.66) \mathrm{kg} / \mathrm{m}^{2}$ and Santa Catarina $24.67( \pm 3.31) \mathrm{kg} /$ $\mathrm{m}^{2}$. In relation to gender, males were above the healthy BMI of $25.66( \pm 3.45) \mathrm{kg} / \mathrm{m}^{2}$, while 
females were within acceptable levels of $24.06( \pm$ $3.45) \mathrm{kg} / \mathrm{m}^{2}$.

Ninety point five eight $(90.58 \%)$ of those surveyed were non-smokers (Table 1). The state with the most smokers was the Rio Grande do Sul, with $7.51 \%$. The average for the sample who stated that they were smokers was $6.90 \%$ although it needs to be noted that $2.50 \%$ of those covered in the survey did not respond to the question. If the numbers are broken down by gender it can be seen that $6.75 \%$ of the male respondents were smokers, and for females the figure was $6.93 \%$.

A large percentage of fitness academy patrons $(49.56 \%)$ do not drink alcoholic beverages. Of those who do consume alcoholic beverages, they do not drink more than twice a week $(39.77 \%)$. When the gender percentages are compared it can be seen that $44.79 \%$ of males are in the habit of drinking alcohol twice a week while the vast majority of females $(55.19 \%)$ stated that they did not consume alcohol.

Table 1. Consumption profile in relation to the states surveyed.

\begin{tabular}{|c|c|c|c|c|c|c|c|c|}
\hline & \multicolumn{2}{|c|}{ Paraná } & \multicolumn{2}{|c|}{$\begin{array}{l}\text { Santa } \\
\text { Catarina }\end{array}$} & \multirow{2}{*}{$\begin{array}{l}\text { Rio } \\
\text { Sul } \\
\mathrm{N}\end{array}$} & \multirow{2}{*}{$\begin{array}{ll}\text { G. } & \text { do } \\
\% & \\
\end{array}$} & \multicolumn{2}{|c|}{ Total } \\
\hline & $\mathrm{N}$ & $\%$ & $\mathrm{~N}$ & $\%$ & & & $\mathrm{~N}$ & $\%$ \\
\hline \multicolumn{9}{|l|}{ Smoker } \\
\hline Yes & 22 & 7.05 & 17 & 6.25 & 16 & 7.51 & 55 & 6.90 \\
\hline No & 278 & 89.10 & 250 & 91.91 & 194 & 91.08 & 722 & 90.59 \\
\hline Did Not Respond & 12 & 3.85 & 5 & 1.84 & 3 & 1.41 & 20 & 2.51 \\
\hline \multicolumn{9}{|l|}{ Alcohol Consumption } \\
\hline None & 168 & 53.85 & 117 & 43.01 & 110 & 51.64 & 395 & 49.56 \\
\hline 2 times per week & 106 & 33.97 & 123 & 45.22 & 88 & 41.31 & 317 & 39.77 \\
\hline 3 times per week & 21 & 6.73 & 25 & 9.19 & 7 & 3.29 & 53 & 6.65 \\
\hline 4 times per week & 3 & 0.96 & 2 & 0.74 & 5 & 2.35 & 10 & 1.25 \\
\hline More than 5 times per week & 2 & 0.64 & 1 & 0.37 & 1 & 0.47 & 4 & 0.50 \\
\hline Did Not Respond & 12 & 3.85 & 4 & 1.47 & 2 & 0.94 & 18 & 2.26 \\
\hline \multicolumn{9}{|l|}{$\begin{array}{l}\text { Consumption of Food } \\
\text { Suplements }\end{array}$} \\
\hline Yes & 125 & 40.06 & 114 & 41.91 & 61 & 28.64 & 300 & 3.64 \\
\hline No & 177 & 56.73 & 155 & 56.99 & 149 & 69.95 & 481 & 60.35 \\
\hline Did Not Respond & 10 & 3.21 & 3 & 1.10 & 3 & 1.41 & 16 & 2.01 \\
\hline
\end{tabular}

With regard to the consumption of dietary supplements, most of the respondents $60.35 \%$ did not consume any product of this nature, while $37.64 \%$ said they used some form of supplements such as proteins, carbohydrates, diet pills or stimulants, giving an average consumption 0.69 supplement per person. For those who used consumed supplements the rate for males was $55.83 \%$, while the female percentage was just $24.46 \%$.

People who attend academies practice on the average 1.34 modalities, of which most practiced individual activities $(62.71 \%)$ without personalized supervision. These individual modalities include such activities as weight training, running and cycling. Twenty point five percent $(20.50 \%)$ of respondents practiced group activities such as; team sports and gymnastics in group. Personalized supervised activities accounted for
$8.94 \%$ of the total while low-impact activities such as Pilates and Yoga account for a further $7.83 \%$. Males $(76.22 \%)$ had a higher incidence of choice for the practice of individual exercise without personalized supervision (Table 2), when compared to that of females at $(54.71 \%)$. 
Table 2. Modalities practiced in southern Brazil in relation to the states surveyed.

\begin{tabular}{|c|c|c|c|c|}
\hline Activities & $\begin{array}{l}\text { South } \\
\text { Brazil }\end{array}$ & Paraná & Santa Catarina & Rio G. do Sul \\
\hline Low Impact & $7.83 \%$ & $11.00 \%$ & $4.93 \%$ & $6.14 \%$ \\
\hline Collective Activities & $20.50 \%$ & $22.01 \%$ & $14.51 \%$ & $25.82 \%$ \\
\hline Individual Activities & $62.71 \%$ & $59.02 \%$ & $72.53 \%$ & $56.15 \%$ \\
\hline Personalized Training & $8.94 \%$ & $7.96 \%$ & $8.02 \%$ & $11.89 \%$ \\
\hline
\end{tabular}

There was no statistical difference (Quesquare test $(\chi 2)$ with a value of 9.532 , with 6 degrees of freedom and $\mathrm{p}$-value $=0.146$ ) between the percentage of activities practiced in the three states studied (Table 3). This means that the southern region is homogeneous in its physical activity practice profile.

Survey participants have, going to the gym to practice exercise every week, as a priority in their lives. Thirty-four point one three percent $(34.13 \%)$ of respondents sought to use the gym five times a week, and nineteen point seven percent (19.70\%) three times a week. The less frequently cited use was twice a week, at $8.53 \%$. Males were more assiduous to training programs than females; with $21.47 \%$ of males visiting an academy more than five times a week, while only $11.90 \%$ females visited the academy with the same frequency. The percentage of the participants of the survey who frequented an academy five times per week were; female $(28.14 \%)$ and male $(41.72 \%)$.

Table 3. Frequency and profile of sport in relation to the states surveyed.

\begin{tabular}{|c|c|c|c|c|c|c|c|c|}
\hline & \multicolumn{2}{|c|}{ Paraná } & \multicolumn{2}{|c|}{$\begin{array}{l}\text { Santa } \\
\text { Catarina }\end{array}$} & \multirow{2}{*}{$\begin{array}{l}\text { Rio } \\
\text { Sul } \\
\mathrm{N}\end{array}$} & \multirow{2}{*}{$\begin{array}{ll}\text { G. do } \\
\%\end{array}$} & \multicolumn{2}{|c|}{ Total } \\
\hline & $\mathrm{N}$ & $\%$ & $\mathrm{~N}$ & $\%$ & & & $\mathrm{~N}$ & $\%$ \\
\hline \multicolumn{9}{|l|}{ Weekly Frequency } \\
\hline 2 times per week & 9 & 2.88 & 8 & 2.94 & 51 & 23.94 & 68 & 8.53 \\
\hline 3 times per week & 62 & 19.87 & 39 & 14.34 & 56 & 26.29 & 157 & 19.70 \\
\hline 4 times per week & 61 & 19.55 & 64 & 23.53 & 25 & 11.74 & 150 & 18.82 \\
\hline 5 times per week & 114 & 36.54 & 106 & 38.97 & 52 & 24.41 & 272 & 34.13 \\
\hline More than 5 times per week & 52 & 16.67 & 51 & 18.75 & 23 & 10.80 & 126 & 15.81 \\
\hline Did Not Respond & 14 & 4.49 & 4 & 1.47 & 6 & 2.82 & 24 & 3.01 \\
\hline \multicolumn{9}{|l|}{ Objective of physical activity* } \\
\hline Health & 211 & 39.66 & 186 & 40.35 & 155 & 42.12 & 552 & 40.56 \\
\hline Aesthetics & 154 & 28.95 & 112 & 24.30 & 101 & 27.45 & 367 & 26.97 \\
\hline To Feel Good & 167 & 31.39 & 163 & 35.36 & 112 & 30.43 & 442 & 32.48 \\
\hline \multicolumn{9}{|l|}{ Distance of acadamy from home } \\
\hline Within $500 \mathrm{~m}$ & 73 & 23.40 & 52 & 19.12 & 38 & 17.84 & 163 & 20.45 \\
\hline Between $500 \mathrm{~m}$ and $1 \mathrm{~km}$ & 63 & 20.19 & 61 & 22.43 & 39 & 18.31 & 163 & 20.45 \\
\hline Between $1 \mathrm{~km}$ and $2 \mathrm{~km}$ & 54 & 17.31 & 85 & 31.25 & 34 & 15.96 & 173 & 21.71 \\
\hline Between $2 \mathrm{~km}$ and $5 \mathrm{~km}$ & 68 & 21.79 & 49 & 18.01 & 40 & 18.78 & 157 & 19.70 \\
\hline More than $5 \mathrm{~km}$ & 39 & 12.50 & 18 & 6.62 & 52 & 24.41 & 109 & 13.68 \\
\hline Did not Respond & 15 & 4,81 & 7 & 2,57 & 10 & 4,69 & 32 & 4,02 \\
\hline \multicolumn{9}{|l|}{ Period that frequente acadamy* } \\
\hline Morning & 73 & 21,53 & 79 & 25,99 & 47 & 21,08 & 199 & 22,98 \\
\hline Afternoon & 117 & 34,51 & 120 & 39,47 & 75 & 33,63 & 312 & 36,03 \\
\hline Night & 149 & 43,95 & 105 & 34,54 & 101 & 45,29 & 355 & 40,99 \\
\hline
\end{tabular}

*possibility of more than one response.

The principle reason interviewees gave for frequenting a gym was for health reasons, $40.55 \%$. The least reason cited was for aesthetic benefits at $26.96 \%$. When broken down into gender, both males and females sought to practice a physical activity in order to improve their health $(39.74 \%$ and $41.07 \%$ respectively). The desire for aesthetic benefits also ranked last.

Forty point nine, nine percent $(40.99 \%)$ of those interviewed preferred to attend an academy at night, thirty-six point zero two per cent $(36.02 \%)$ in the late afternoon / early evening and finally twenty- 
two point nine seven percent $(22.97 \%)$ in the morning. Both genders prefered to attend the gym at night.

The most significant factor in choosing a place to exercise, according to regular academy clients (20.37\%) in southern Brazil, was the distance from their home to the gym (Table 4). Professional qualification of instructors at $19.18 \%$ was the next citied reason, followed by the time the interviewees needed to be present at their place of work (17.52\%). When the figures are broken down into gender, males $(21.52 \%)$ chose as their primary factor the distance to the academy, and secondly the quality of the equipment (20.06\%). Females also stated the distance of the academy from their residence $(19.76 \%)$ as the most important factor, but in second place was the professional qualification of the academy staff $(19.10 \%)$.

Table 4. Academy choice factors in relation to states and gender

\begin{tabular}{|c|c|c|c|c|}
\hline & $\begin{array}{l}\text { Total } \\
\%\end{array}$ & $\begin{array}{l}\text { Paraná } \\
\%\end{array}$ & $\begin{array}{l}\text { Santa } \\
\text { Catarina } \\
\%\end{array}$ & $\begin{array}{l}\text { Rio G. do Sul } \\
\%\end{array}$ \\
\hline Opening Hours & 17.52 & 17.02 & 16.78 & 19.16 \\
\hline Distance from Residence & 20.37 & 23.08 & 19.22 & 17.62 \\
\hline Professional Qualification & 19.18 & 16.14 & 23.78 & 18.39 \\
\hline Modalities Available & 8.24 & 8.07 & 6.19 & 10.92 \\
\hline Monthy Acadamy Fee & 16.54 & 15.64 & 15.31 & 19.35 \\
\hline Equipment Quality & 17.00 & 17.91 & 18.24 & 14.18 \\
\hline Others & 1.14 & 2.14 & 0.49 & 0.38 \\
\hline
\end{tabular}

On average 2.48 factors were taken into account when a client sought an academy to practice exercise in. Paraná with on average 2.64 criteria in choosing an academy was the most demanding state. It was followed by Rio Grande do Sul at 2.51 reasons and lastly Santa Catarina at on average 2.27 reasons. Males at 2.16 reasons were less critical than females at an average 2.71 criteria, when they chose the environment to practice their physical activities.

Knowing that the most important motive in choosing a gym is the distance from a client's residence, the question; "What is the distance between your home and your academy" was asked? Most replied $(21.71 \%)$ that the academy was between one and two kilometers from their home. When broken down by gender; males $(24.23 \%)$ opted for gyms that were between one and two kilometers from home but females (21.00\%) preferred academies between 500 meters to one kilometer from their place of residence.

The average financial investment in fitness training in the area surveyed was R \$158.79. When broken down into states; Paraná had the highest investment cost at R $\$ 187.52$, followed by Santa Catarina at R\$144.93 and Rio Grande do Sul at R\$ 133.85. When considering gender, males tended to invest more, with an average total of $\mathrm{R} \$ 179.61$, while females spent an average of $\mathrm{R} \$ 142.33$.

\section{DISCUSSION}

A surprising result was the low incidence of consumption of addictive products such as cigarettes and alcohol by Brazilians who frequent fitness academies. Approximately half $(49.56 \%)$ of those interviewed did not consume alcohol regularly. The cigarette consumption indicator for fitness academy clients, at just $6.90 \%$, is very low considering the data provided by Malta et al (2014), which indicates that currently $10.8 \%$ of Brazilians smoke. It is clear therefore that the people attending academies in southern Brazil are less likely to have a tobacco addiction than the general population. The index provided by Vigilância de fatores de risco $e$ proteção para doenças crônicas por inquérito telefônico (VIGITEL, 2013) points out that the habit of smoking is higher among males (12.8\%) than among females (9\%). In this study the indicators appear to be reversed; females having a higher frequency of cigarette addition than males.

Morales (2002) research conducted in the city of Joinville/SC found that $17.1 \%$ of fitness academy clients were smokers and $45.9 \%$ of respondents did not drink. In the same state, in this present study (Santa Catarina) the index was much lower. In this study it was found that only $6.25 \%$ of the population were smokers (the state with the lowest number of smokers when compared to the other sampling). This discrepancy is probably due to the date of the study. According to DGS (2013), there has been a significant drop in recent years in 
the numbers of the world's population who smoke. DGS figures show that $28 \%$ of the populations of Europe are smokers, which is considerably higher than the Brazilian rate.

In relation to the consumption of dietary supplements it was found that $37.64 \%$ of those interviewed were using such products. Other research shows that consumption is significantly higher in different centers of the country. Hirschbruch, Fisberg, \& Mochizuki (2008) showed in their survey in São Paulo/SP that the use of supplements is reported to be $61.2 \%$. Research by Silveira, Lisbôa e Sousa (2011) Brasilia/DF, found that $53 \%$ of respondents claim to consume some form of dietary supplement. However, Fayh, Silva, Jesus \& Costa (2013) observed in Porto Alegre/RS a lower use of nutritional supplements found than in this present study (28.8\%), but very close to that found in Rio Grande do Sul, which has the lowest average of the three states in this criterion at $28.63 \%$.

The modality most widely practiced; at $62.75 \%$ in this survey was the practice of individual exercises. This result was similar to that found in several studies (SILVEIRA 2011, NUVIALA 2012, MODESTO 2016), showing compliance with the current literature and consciousness on the benefits of resistance training (ACSM, 2006). However, SaSilva, Sandre-Pereira, \& Salles-Costa (2011) found different results. Their results showed that group activities such as the practicing of football amongst males, was the predominant type of activity. In their study, females tended to choose low intensity activities such as walking. Thus there is a difference in research results, in comparison to this present study.

The most quoted weekly rate of attendance at fitness academies was five times a week (34.13\%) demonstrating controversial data with the current literature. Bertulucci, et al (2010) found participants in survey exercised every day. Carvalho (2011) noted that attendance of 3 to 4 times per week was more common. Ferreira (2012), states that people attend the gym on average two or three times a week. Gonçalves (2012) found that the majority of the members worked out twice a week.

When clients begin attending an academy to practice an activity, the most quoted reason (40.55\%) for exercising is because of the perceived health benefits. This health concern is also evidenced in the literature (FERMINO 2010; ASCENSÃO 2012; IHRSA 2014). Following along the same lines, Liz et al (2010) states that the most cited reasons for practicing exercise was for "health" and "aesthetic" reasons. Silveira et al (2011) found aesthetic concerns were more predominant, in which males wanted to increase muscle volume, while females sought to lose weight.

In this study, the state of Santa Catarina showed that $40.34 \%$ of client's attended academies in order to improve their health, followed by the desire to feel good about themselves and finally for aesthetic reasons. The research conducted in the same state as that conducted by a study of Soares (2004) showed similar results. In other literature (MORALES, 2002; BOSSI et al, 2008) the result was controversial. In that study aesthetic factors were seen as the principal reason people attended fitness academes, followed by health and wellbeing goals.

In this study, distance between an academy and their residence was the main factor $(20.37 \%)$ in clients choosing an academy in which to train. Zannete (2003) found that in Rio Grande do Sul the quality of teachers in academies was the key aspect in choosing a gym. In this present study, the qualification of fitness center professionals was the second most cited item, although in the state of Santa Catarina this criterion was cited as the most important.

Gonçalves, Buchmann, \& Carvalho (2013) also found that in Rio Grande do Sul good facilities and modern equipment are fundamental factors in selecting an academy. In this present study it was found for $19.35 \%$ of those interviewed that the monthly gym attendance fee rated as a higher factor, with the quality of facilities and equipment being fifth placed criterion at $14.18 \%$, demonstrating the difference between the two surveys.

For those who responded distance as being the most important factor in choosing a gym, most of those sampled $(21.71 \%)$ responded their academy is located between one and two kilometers from their place of residence. Morales (2002) in his survey in Santa Catarina stated that his subjects lived within $2.5 \mathrm{~km}$ of the academy. Bartolomeu Neto et al (2013) reported that most of the participants of their survey attended the nearest gym to their residence at a distance less than one kilometer.

Liz et al (2010) and Bartholomeu Neto et al (2013) contrary to this present study found that the clients reported that the main reasons they stopped attending fitness academies was due to; a lack of time, lack of motivation, distance of to the academy, monetary constraints and problems with classes and instructors.

When the preferred time to attend an academy was verified this survey found that 
$40.99 \%$ of those surveyed preferred to attend the gym in the evening. Zanette (2003) also found similar results and associated the standard eighthour work day and the number of evening classes offered by gyms as being the principal reason. As Zanette (2003) research is now old, this view can be questioned, as more recent research has found that the most popular activities are the individual, not requiring structured classes.

The average investment in physical exercise training was $\mathrm{R} \$ 158.79$ per month. This value applies to the total amount spent on training and may contain the value on food supplements. The IHRSA (2014) states that in the United States the average amount invested in 2012 was US $\$ 49$ and in Portugal the average price of the academy tuition was 39 Euros. Gonçalves (2012), Portugal, found most spent between 50 to 99 Euros. These results demonstrate that residents of southern Brazil invest a large portion of their income on training compared to those in Portugal and America.

Although the most important reason cited by academy clients in southern Brazil for choosing a gym, is the distance between academy and their residence (a reason that could be considered subjective), there is the possibility that the practice of exercise in an academy is in fact addictive. As the reason given for exercising in southern Brazil is the pursuit of the health benefits, and the rest of Brazil and in Europe to seek cosmetic improvement, it may argued that in southern Brazil academy attendance is less additive. This is a controversial assumption.

\section{CONCLUSIONS}

It was observed that those who attend fitness academies covered by this present study; smoked little, consumed few food supplements and $50.44 \%$ were moderate drinkers.

The most practiced type of exercise was intense individual activities, there being no statistical difference between the percentages in the three states under study. The southern region states were homogeneous in their physical activity practice profile.

The majority $(34.13 \%)$ of fitness academy clients in southern Brazil choose to go to the gym five times a week, at night $(40.99 \%)$, with the objective of improving their health $(40.56 \%)$.

Finally, it was observed that $40.90 \%$ of the fitness academy clients in southern Brazil prefer to conduct their activities in establishments located less than a kilometer away from the place of residence $(40.90 \%)$.

RESUMO: O Brasil ocupa o segundo lugar do mundo em número de academias, totalizando 23.398 unidades com cerca de sete milhões de frequentadores, ficando atrás apenas dos EUA. Neste sentido, o objetivo desse estudo foi delinear o perfil dos praticantes de atividade física supervisionada, analisando os motivos que os levam a escolher um serviço de fitness, bem como traçar o perfil de consumo de álcool, tabaco e suplementos alimentares dos habitantes da Região Sul do Brasil. Foram avaliadas 797 pessoas através de um questionário próprio. A coleta foi realizada em 24 academias divididas em oito para cada um dos três estados do Sul do Brasil. Observou-se que os frequentadores de academias da área de abrangência da pesquisa fumam pouco, consomem poucos suplementos alimentares e apenas 50,44\% dessa população consome bebidas alcoólicas de maneira moderada. A maior parte $(34,13 \%)$ dos praticantes de exercício físico do Sul do Brasil optam por frequentar a academia cinco vezes por semana, no período noturno (40,99\%), com o intuito de melhorar a saúde $(40,56 \%)$. A distância entre a residência e a academia se mostrou o motivo mais relevante para escolher um locar para realizar o treinamento. $\mathrm{O}$ tipo de exercício mais praticado são as atividades individuais mais intensas e não houve diferença estatística entre os percentuais nos três estados estudados.

PALAVRAS-CHAVE: Perfil da prática esportiva. Academias do Sul do Brasil. Perfil de consumo.

\section{REFERENCES}

AMERICAN COLLEGE OF SPORTS MEDICINE - ACSM. Recursos do ACSM para o Personal Trainer. 1. ed. Rio de Janeiro: Guanabara Koogan. 2006

AMERICAN COLLEGE OF SPORTS MEDICINE - ACSM. Diretrizes do ACSM para os testes de esforço e sua prescrição. 4. ed. Rio de Janeiro: Guanabara Koogan. 2007 
ASCENSÃO, R. P. A. Motivação para a prática de exercício físico em ginásios do distrito de Castelo Branco. Thesis (master of physical activity) - Escola Superior de Educação, Instituto Politécnico de Castelo Branco, Portugal. 2012. Available at: <http://repositorio.ipcb.pt/handle/10400.11/1981>. Accessed on: 10 jan. 2016.

BARTHOLOMEU NETO, J.; PINTO, J. S.; SILVA, J. V. P; SALES, M. M.; CÓRDOVA, C.; PEREIRA, L. A.; ASANO, R. Y. Motivos do abandono de academias de ginástica por universitários com sobrepeso ou obesidade Revista Brasileira de Ciência e Movimento, Brasilia, v. 21, n. 3, p. 96-104, 2013. Available at: <http://portalrevistas.ucb.br/index.php/RBCM/article/viewArticle/3714>. Accessed on: 12 jan. 2016

BERTULUCCI, K. N. B.; SCHEMBRI, T.; PINHEIRO, A. M. M.; NAVARRO, A. C. Consumo de suplementos alimentares por praticantes de atividade física em academias de ginástica em São Paulo. Revista Brasileira de Nutrição Esportiva, São Paulo, v. 4, n. 20, p. 165-172. 2010. Available at: $<$ http://www.rbne.com.br/index.php/rbne/issue/view/29/showToc>. Accessed on: 10 jan. 2016

BOSSI, I.; STOEBERL, R.; LIBERALI, R. Motivos de aderência e permanência em programas de musculação. Revista Brasileira de Prescrição e Fisiologia do Exercício, São Paulo, v. 2, n. 12, p. 629-638, 2008. Available at: <http://www.rbpfex.com.br/index.php/rbpfex/article/viewFile/437/445>. Accessed on: 11 jan. 2016

CARVALHO, R. O. Emoção, satisfação e lealdade no fitness. Thesis (Master in Sports Management) Faculdade de Motricidade Humana, Universidade Técnica de Lisboa, Portugal. 2011.

DIREÇÃO GERAL DE SAÚDE DE PORTUGAL - DGS. Prevenção e controlo do tabagismo. Portugal. 2013. Available at: <https://www.dgs.pt/>. Accessed on: 10 jan. 2016.

FAYH, A. P. T.; SILVA, C. V. D.; JESUS, F. R. D. D.; COSTA, G. K. Consumo de suplementos nutricionais por frequentadores de academias da cidade de Porto Alegre. Revista Brasileira de Ciência do Esporte, Florianópolis, v. 35, n. 1, p. 27-37, 2013. Available at: <http://www.scielo.br/pdf/rbce/v35n1/a04v35n1>. Accessed on: 12 jan. 2016

FERMINO, R. C.; PEZZINI, M. R.; REIS, R.S. Motivos para prática de atividade física e imagem corporal em frequentadores de academia. Revista brasileira de medicina do esporte, São Paulo, v. 16, n.1, p.18-23. 2010. Available at: <http://www.scielo.br/scielo.php?script=sci_arttext\&pid=S1517-86922010000100003> Accessed on: 11 jan. 2016.

FERREIRA, C. M. C. Um estudo sobre fidelização e retenção de clientes na área do fitness. 2012. Thesis (Master in business management) - Escola Superior de Gestão. Instituto Politécnico de Castelo Branco, Portugal. 2012. Available at: <http://repositorio.ipcb.pt/handle/10400.11/1701>. Accessed on: 10 jan. 2016.

GONÇALVES, C. R. N. Retenção de sócios no fitness: estudo do posicionamento, expectativas, bem-estar e satisfação. 2012. Thesis (PhD in human movement) - Faculdade de Motricidade Humana, Universidade Técnica de Lisboa, Portugal. 2012. Available at: <https://bibliotecadigital.ipb.pt/handle/10198/7697> Accessed on: 10 jan. 2016

GONÇALVES, C.; BUCHMANN, C.; CARVALHO, M. J. Percepção da Qualidade do serviço e satisfação dos sócios no fitness: Contribuição para o papel do gestor. Revista Intercintinental de Gestão Desportiva, Bragança, v. 3, n. 2, p. 47-58. 2013.

HIRSCHBRUCH, M. D.; FISBERG, M.; MOCHIZUKI, L. Consumo de suplementos por jovens frequentadores de academias de ginástica em São Paulo. Revista Brasileira de Medicina do Esporte, São Paulo, v. 14, n. 6, p. 539-43, 2008. Available at:

$<$ http://few.universoef.com.br/container/gerenciador_de_arquivos/arquivos/48/consumo-de-suplementos-porjovens-frequentadores.pdf>. Accessed on: 10 jan. 2016 
INSTITUTO BRASILEIRO DE GEOGRAFIA E ESTATÍSTICA - IBGE Censo Demográfico 2010. Rio de Janeiro, 2010. Available at: <http://www.ibge.gov.br/home/estatistica/populacao/censo2010>. Accessed on: 16 jul. 2014.

INTERNATIONAL HEALTH RACQUET \& SPORTS CLUB ASSOCIATION - IHRSA. The IHRSA Global Report on the State of the Health Club Industry. Boston, 2014. Available at: <http://www.ihrsa.org/>. Accessed on: 16 abril 2015.

LIZ, C. M.; CROCETTA, T. B.; VIANA , M. S.; BRANDT, R.; ANDRADE, A. Aderência à prática de exercícios físicos em academias de ginástica. 2010. Motriz, Rio Claro, v.16 n.1 p.181-188, 2010. Available at: $<$ https://www.researchgate.net/profile/Ricardo_Brandt/publication/270178452_Aderncia_prtica_de_exerccios _fsicos_em_academias_de_ginstica/links/552d7a220cf29b22c9c4f583.pdf>. Accessed on: 10 jan. 2016

MALTA, D. C., ANDRADE, S. C., CLARO, R. M., BERNA, R. T. I.; MONTEIRO, C. A. Evolução anual da prevalência de excesso de peso e obesidade em adultos nas capitais dos 26 estados brasileiros e no Distrito Federal entre 2006 e 2012. Revista Brasileira de Epidemiologia, São Paulo, v. 17, n. ssupl 1, p. 267-276. 2014.

Available at: <http://www.scielo.br/pdf/rbepid/v17s1/pt_1415-790X-rbepid-17-s1-00267.pdf>. Accessed on: 10 jan. 2016

MINISTÉRIO DA SAÚDE DO BRASIL - MSB. Avaliação de efetividade de Programas de Atividade Física no Brasil. 1. ed. Brasília: MS, 2013.

MODESTO, J. D; ULBRICHT, L.; NEVES, E. B. Satisfação de Clientes em Serviços de Educação Física Supervisionada na Região de Curitiba, Brasil: Aplicação do QSCSEF. Motricidade. v. 12, n. 2, p. 48-58, 2016. Available at: <http://revistas.rcaap.pt/motricidade/article/view/6872/5149>. Accessed on: 10 jan. 2016

MORALES, P. J. C. Iniciação, aderência e abandono nos programas de exercícios físicos oferecidos por academias de ginástica na região de Joinville. 2002. Thesis (Master in physical education) - Curso de Educação Física, Universidade Federal de Santa Catarina, Florianópolis, 2002.

MOURA, E. C. D., MORAIS NETO, O. L. D., MALTA, D. C., MOURA, L. D., SILVA, N. N. D., BERNAL, R. T. I., MONTEIRO, C. A.. Vigilância de fatores de risco para doenças crônicas por inquérito telefônico nas capitais dos 26 estados brasileiros e no Distrito Federal (2006). Revista Brasileira de Epidemiologia, São Paulo, n. 11, v.1, p. 20-37. 2008. Available at: <http://www.repositorio.ufpa.br/jspui/handle/2011/3748>. Accessed on: 10 jan. 2016. https://doi.org/10.1590/s1415-790x2008000500003

NUVIALA, A. N.; GRAO-CRUCES, A., PÉREZ-ORDÁS, R.; OSUNA, M. B.; NUVIALA, R. N.; JURADO, J. A. G. Calidad, satisfacción y valor percibido de los usuarios de un servicio deportivo público. Movimento, Porto Alegre, v. 18, n.4, p. 11-32. 2012. Available at: <http://seer.ufrgs.br/Movimento/article/download/23828/23446>. Accessed on: 11 jan. 2016

SÁ SILVA, S. P.; SANDRE-PEREIRA, G.; SALLES-COSTA, R. Fatores sociodemográficos e atividade física de lazer entre homens e mulheres de Duque de Caxias/RJ. Ciências e saúde coletiva, Rio de Janeiro, v. 16 n. 11, p. 4491-4501. 2011. Available at: <http://www.scielo.br/scielo.php?script=sci_arttext\&pid=S141381232011001200022> Acessado em: 12 jan. 2016

SERVIÇO BRASILEIRO DE APOIO ÀS MICROS E PEQUINAS EMPRESAS. SEBRAE. 2015. Available at: <http://www.sebrae.com.br>. Accessed on: 08 jan. 2016

SILVEIRA, D. F.; LISBÔA, S. D.; DE SOUSA, S. Q. O consumo de suplementos alimentares em academias de ginástica na cidade de Brasília-DF. Revista Brasileira de Nutrição Esportiva, São Paulo, v. 5 n. 25. p. 0513. 2011. Available at: <http://www.rbne.com.br/index.php/rbne/article/viewFile/226/215>. Accessed on: 12 jan. 2016 
SOARES, T. C. M. Motivação e aderência de mulheres ativas: um estudo dos fatores determinantes da atividade física. 2004. Thesis (master in physical education) - Curso de Educação Física, Universidade Federal de Santa Catarina, Florianópolis, 2004.

SOLER, P. T.; FERNANDES, H. M.; DAMASCENO, V. O.; NOVAES, J. S. Vigorexia e níveis de dependência de exercício em frequentadores de academias e fisiculturistas. Revista brasileira de medicina do esporte, São Paulo, v. 19, n. 5, p. 343-348. 2013. Available at:

<http://www.scielo.br/scielo.php?script=sci_arttext\&pid=S1517-86922013000500009>. Accessed on: 12 jan. 2016.

VIGILÂNCIA DE FATORES DE RISCO E PROTEÇÃO PARA DOENÇAS CRÔNICAS POR INQUÉRITO TELEFÔNICO - VIGITEL. Ministério da Saúde. Secretaria de Vigilância em Saúde do Brasil 2012: Brasília: Ministério da Saúde, 2013

WORLD HEALTH ORGANIZATION. Nutrition, Physical Activity and Obesity Portugal. Switzerland, 2008. Available at: <http://www.euro.who.int/>. Accessed on: 10 jan. 2016

WORLD HEALTH ORGANIZATION. Country profiles on nutrition, physical activity and obesity in the 28 European Union Member States of the WHO European Region. Switzerland, 2014. Available at: $<$ http://www.euro.who.int/>. Accessed on: 10 jan. 2016

ZANETTE, E. T. Análise do perfil dos clientes de academias de ginástica: o primeiro passo para o planejamento estratégico. 2003. Thesis (Master of Engineerings) - Escola de Engenharia, Universidade Federal do Rio Grande do Sul, Porto Alegre, 2003. Available at: <http://www.lume.ufrgs.br/handle/10183/3601>. Accessed on: 10 jan. 2016 